\title{
YULETIDE IDEOLOGY AS ADVERTISING IDEOLOGY: AN HISTORICAL ILLUMINATION FROM SAINT NICHOLAS TO THE PRESENT DAY
}

\author{
UDC 659.1:27-36 Nikola, sveti
}

\section{Taofeek Dalamu}

\author{
Department of English, University of Lagos, Akoka, Yaba, Lagos, Nigeria
}

\begin{abstract}
The study traces the historical phenomenon of Saint Nicholas, the renowned icon known as Santa Claus. The objective is to demonstrate how advertisers have seized the virtues of Santa Claus as an article of persuading consumers. Owing to the interdisciplinary nature of this enquiry exemplified in the domains of history, linguistics and advertising, the concept of ideology enraptured in interpellation is adopted as both the analytical tool and discursive assistant to unravel the data meaning-making potentiality. The author utilizes twelve adverts associated with Santa Claus as illustrations in which six of them are from the Coca-cola Company ${ }^{\circledR}$ as a reference of honour as well as a signal to the role the institution plays in promoting the heroic persona. The study reveals the universality and acceptability of Santa Claus in global affairs during the Yuletide season. That hegemonic influence is perceived as motivation for advertisers to project Santa Claus in a civilized way as a cook, a dove or an angel, a car lover or owner, an alcoholic or a lover of alcohol, and a banker. Santa Claus with his traditional values enthralled in kindness to humanity is further represented as a parsimonious person somehow addicted to sugary contents without any unhealthy resultant effects. In all, the traditional etiquette of Santa Claus established by Saint Nicholas and promoted by Coca-cola ${ }^{\circledR}$, the study suggests, is worthy of emulation for all. Perhaps, through such characteristic adoption the political violence and terrorism intimidating the world can be laid to rest in no time and at less cost.
\end{abstract}

Key words: Advertising, Coca-Cola ${ }^{\circledR}$, Ideology, Interpellation, Santa Claus

\section{INTRODUCTION}

Advertising does not operate in isolation. It attaches itself to one phenomenon or another in order to make meaning and serve its purpose. In other words, parasitism is a

Submitted April $19^{\text {th }} 2017$, accepted for publication December $13^{\text {th }}, 2017$

Corresponding author: Taofeek Dalamu

Department of English, University of Lagos, Akoka, Yaba, Lagos, Nigeria

E-mail: lifegaters@yahoo.com 
concept that facilitates advertising functions. That is, other events bear the burden of its operations in all ramifications. That principle has paved the way for its total submission to and dependency on characteristics of other elements. In that regard, the Feyerabend's maxim of 'anything goes' is invaluable in advertising propagations (Feyerabend, 1970, 10). One of the events in that regard that has permanently created an inseparable link with advertising is the historical entity. Of importance is the alignment of the legendary Saint Nicholas popularly known as Santa Claus with the Yuletide and how advertising has successfully accurately documented its activities. Perhaps, the application and importance of Santa Claus during the season have grown great feathers that fly into all the nooks and crannies of families without a religious check. The unrestricted check of the event has been perceived in advertising as an avenue to reach the audience with some products in order to convince them of its consumption. Advertising experts are opportunists who create frames with historical materials in order to overcome and overrule the possibility of the audience ignoring the message meant for them. Harper's Weekly $(1897,42)$ has long recognised this by characterising advertising as 'a true mirror of life, a fossil history from which the future chronicler, if all other historical monuments were to be lost might fully and graphically rewrite the history of our time.' The statement subscribes to three things thus: advertising is very conscious of the target audience's cultural values; it connects the past to the present; and within its capacity, it protects the data of the past. Although the concept of ephemeralism is germane in advertising, it strongly fraternises with the reconstruction of the cultural elements of the past to convince the present consumers. In that wise, advertising can become a historical object in dual senses. It is an object of history and integrates historical components to propagate its beautiful ideas.

From the observation of Goldman,

Advertising has become a form of internal cultural colonialism that mercilessly hunts out and appropriates those meaningful elements of our cultural lives that have value. Its dissolving influence on culture may be advertising's most significant and haunting historical consequence (Goldman 1992, 6).

The cultural treasures of the past become a dose for influencing the consumers, hoping that the culture of the people is a means of unification between them and the advertised products. The lives of the living (men and women) are surrounded with several ideas. These thoughts trigger human beings to act in particular directions. These ideological perceptions and actions seem to become norms in the society having been recurring day-by-day. As observed, these perceptive cultural values turn into gaining economic values. In Pollay's sense, advertising is pervasive and persuasive. It has projected itself as a key economic identity and source to manufacturers, government and society (Pollay 1978, 63). Manufacturers are known to be ardent in selling their goods and services to consumers in order to have financial advantage. They, manufacturers, do not usually fold their arms to be watching consumers to behave the way they intend to towards their manufactured products. Forceful attempts are made to cunningly appeal and systematically manipulate consumers in buying their goods and services. One of these approaches is through persuasion.

Advertising, to manufacturers, is a virile social and economic tool that could be employed to influence the minds and decision making of consumers. First, the social aspect of advertising is likely to be connected to the ideas of consumers in relation to their socio-cultural activities. Second, the economic aspect might be linked to the selling 
of products and financial gains that the producers of goods and services derive from the selling of those business entities. That is why Pollay reiterates that advertising is a faithful promoter of our culture. Thus, the communication mirrors the audience in all operations (ibid.). It could be very tactical to have seen advertisers interconnecting the ideologies in human socialisations with the intended products to be sold. Adverts in such occasions, are presented as attractive, exciting and entertaining pieces of persuasion. Advertising moves away from the mundane to using historical social elements that are critical to human ideas to easily convincingly achieve specific aims and objectives of production. As earlier mentioned, one of such seasons of achievements is the Christmas season (Yuletide) when the celebration of the Lord Jesus Christ is a global concern.

Advertisers and manufacturers spare no expense in this season to play an appealing game with their audience as a source of sensitization. How do they process this? Advertisers get their consumers involved in their products' adverts through the sociallyacceptable Father Christmas cultural heritage and ideology instituted by the popular Santa Claus across the globe from 280 A.D. till date. This investigation is not a pioneering word on the discourse of Father Christmas. That statement suggests that there are many academic writings on the subject. As a result, Johnson (1616) describes theatrical demonstrations and challenges of the concept among his followership (also in Johnson 1686). The examination of Woodbridge (1987) focuses some criticisms that puritans leveled against the adoption and promotion of the figure. Of great importance are studies expounding the emanation (Twitchell 2000), and the matchless influence of Coca-Cola (Mikkelson 2014) on Father Christmas during the Yuletide (Staff 2016). Notwithstanding, those studies dwell so much on historical perspectives along with Coca-Cola's promotional etiquettes, and consequently, they neglect the ways that the advertising industry seizes the opportunity to promote and sell various products. Therefore, this study addresses the advertisers' use of the socio-philosophical idea of Santa Claus that preoccupies the lives of the people (men, women, boys, girls and kids) during Christmas as an appealing resource to consumers. Really, the focus is to interconnect three elements (the text, the product and the picture of historical Santa Claus) in the selected adverts (Coca-cola ${ }^{\circledR}$, Mamador $^{\circledR}$, Peugeot ${ }^{\circledR}$, Access Bank ${ }^{\circledR}$, Milo $^{\circledR}$, Maggi ${ }^{\circledR}$, etc.) together to generate meaning. In other words, the paper examines how these elements are harmonised as objects of historical persuasive appeal to the Christmas celebration enthusiasts.

\section{SAINT NiCHOLAS: SANTA Claus’ ChristMas IDEOLOGICAL HistoRY}

The popularity of the concept, Santa Claus, has no regional constraints. Santa Claus is a household name/brand that may be devoid of any ethnic boundaries, or religious bigotry. Probably, religious hegemony of any incalculable height or sophistication is incapacitated to curb the popularity, widespread, acceptability and association that the iconic figure has established with the world over the years because of the fun attached to it. In Nigeria for instance, governments, companies, private and public organizations, families and individuals embrace the notion of Santa Claus as a means of making fun and merriment during Christmas holidays. Religion seems to have failed, as stated earlier, to draw a thin line between the people and Santa Claus. A religious dichotomy seems not to be a considerable factor for people to denounce their love and acceptance for the Christmas Santa Claus. Historically though, the celebration is an imported culture to the Nigerian society; nevertheless, it has come to stay as a representative of a cheerful giver to all classes of people without sentiments. 
It is reported that Santa Claus is a derivative of Saint Nicholas who hailed from southwest of modern Turkey in the fourth-century. He was a Bishop who lived in Lycian port of Myra and died on the $6^{\text {th }}$ of December (Swartz n.d.). Historical facts add that St. Nicholas was born around 280 A.D. in Patara, near Myra in modern-day Turkey. He was admired for his piety and kindness among the people countryside. By renaissance, as Twichell claims, St. Nicholas was the most popular saint in Europe (Twitchell 2000). There are three significances the figure portrays among his people: a gift-giver; a lover of children; and a patron saint. Green (2004) observes that one of the earliest legends attached to St. Nicholas explains how he assisted a man who could not afford dowries for his three daughters and intended to send them to brothel to work. It was St. Nicholas who willingly graciously threw three bags of gold through the window to that family at night in order to rescue the man and his three daughters from the shameful, disgraceful and regrettable intended act. Green further adds that an additional popular tale was told about St. Nicholas when he rescued three children from death, who had been pickled for eating by an inn-keeper. The third line of St. Nicholas attributes was characterised and credited with performing a number of miracles involving children and sailors. The irresistible global evolution of the St. Nicholas concept has propelled his fans to parade the saint with many creative appellations such as: Santa Claus, Father Christmas, Kris Kingle, Old Sait Nick, Sinter Klass, Sinter Klaas, and Sancte Claus. Henceforth, the article adopts Santa Claus for Saint Nicholas for the purpose of harmony. One of the earlier pictures of Santa Claus of 1881 is represented in Image 1.

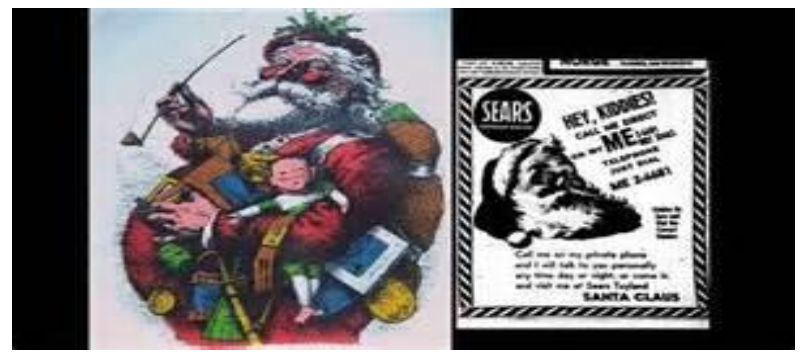

Image 1 Santa Claus of 1881

The fraternity between Santa Claus and Christmas was entwined to be a function of Pope Julius 1. Pope Julius 1, as recounted, decided to establish a date for the celebration of the birth of Jesus, and his intention happened to fall about the same time that Santa Claus lived. As the actual time of the year of Jesus' birth was unknown, the Pope attempted to assign the holiday to December $25^{\text {th }}$. However, there had long been a pagan mid-winter festival at this time of the year and Pope attempted to adopt the holiday to Christianise the celebrations. Eventually, Santa Claus' feast day also became associated with December $25^{\text {th }}$, and his connection was established (see details in www.unmuseum.org, 2003) having been a man who seemingly had accomplished impossible tasks. Despite the Santa Claus achievement, acceptance and influence across the globe, criticisms on the concept loom. The puritans resisted the phenomenon, claiming that it represents syncretism (Swartz n.d.; Green 2012; Johnson 1616 and 1686; Woodbridge 1987). All attempts to suppress or quench the spirit of Santa Claus from people were unsuccessful. The Punch newspaper $(2014,54)$ reports that the attempts in both the medieval and contemporary epochs to 
stamp out Santa Claus resulted to promote the probable 'deity' more and more and heighten its ovation.

Advertisers are seemingly shameless semiotic harlots whose interest is basically connected to any material to be associated with that can heighten the product's image and promote sales (Dalamu 2017b). The Coca-Cola influence on the modern image of Santa Claus cannot be undermined. Santa Claus had been colored in several colours - white, green, blue, brown, red, a red jacket with blue knickerbockers - to represent its apparel before Coca-Cola identified with this legendary entity. History records that in the $20^{\text {th }}$ century Santa Claus was reddened. An all-red outfit with white trimmings became the norm, especially after Coca-Cola advertising campaigns exploited the figure of Santa Claus in 1931 (Simpson and Roud 2001, 314). This attempt might be the major roadmap to advertisers embracing Santa Claus as an object of consumer persuasion. A strong support is offered by Twitchell (2000) who argues that the jolly of St. Nick that people know from countless images did not come from folklore, nor did he originate in the imaginations of Moore and Nast. He comes, Twitchell asserts, from the yearly adverts of the Coca-Cola Company. The icon wears corporate colours - the famous red and white for a reason: he is working out of Atlanta, not of the North Pole. There is no doubt that Coca-Cola contributed immensely with a great influence in promoting the beloved persona of Santa Claus. However, Santa Claus is a hybrid that descended from a pious figure whose modern image is revolutionised by the thoughts and touches of many other contributors - writers, poets, illustrators, artists, advertisers, etc. Hence, images 2, 3, 4, 5, and 6 below indicate the modern appearance of the commercially created Santa Claus by the Coca-Cola Company in 1931, 1950, 1951, 1970 and 1980.
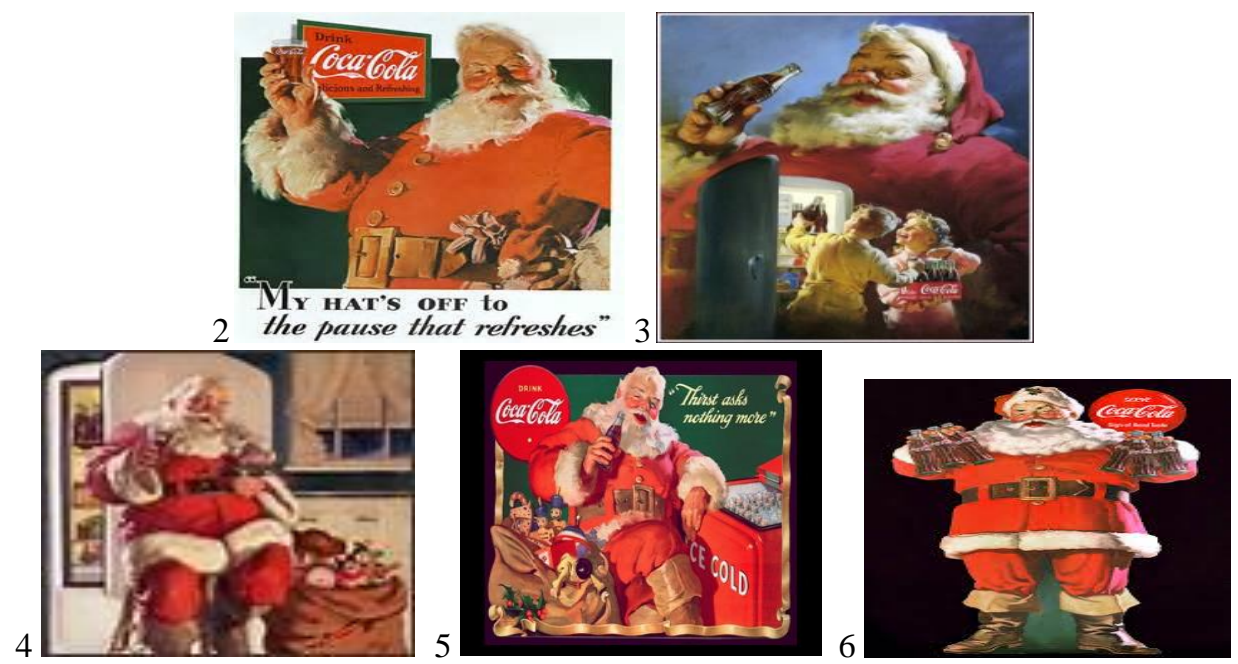

Image 2, 3, 4, 5 \& 6 Santa Claus in 1931, 1950, 1951, 1970 \& 1880

The standardised image, Mikkelson (2014) reports, is a creation of a talented commercial illustrator, Haddon Sundblom, - from Clark Moore's poem 'The Night Before Christmas' with the slogan 'The pause that refreshes' (also in Staff 2014 and 2016). 


\section{THEORETICAL APPRECIATION}

\subsection{Ideology and the quintessence of interpellation}

The theoretical prose on ideology is enormous as adverts appear to associate with relevant materials in several motifs without any bias. The concept of ideology, as far as the writer understands, is a subject in so many disciplines. So, one should expect some diversities in the scholars' opinions on the subject, and most likely to convey divergent meanings (Fairclough 2001, 77). Blommaert (2005) notes that the diversity of scholars' thoughts could be graded into two specifics. The first school experiments ideology as a specific symbol of representations, whereas the second school identifies ideology as a general phenomenon. On that discursive plane, Blommaert argues that,

\footnotetext{
...there are on one hand authors who define ideology as a specific set of symbolic representations - discourses, terms, arguments, images, stereotypes - serving a specific purpose, and operated by specific groups or actors, recognisable precisely by their usage of such ideologies. On the other hand, there are authors who would define ideology as a general phenomenon characterising the totality of a particular social or political system, and operated by every member or actor in that system (Blommaert 2005, 158).
}

The distinction in Blommaert's argument on ideology is the dichotomy recorded in the authors' views. Blommaert accounts for ideology from general and specific dimensions. Specific ideology is a precise concept devoid of ambiguity. It is the exact and possesses definite explanation of terms. The other side of the ideology coin is general in nature. The universality of this expression is for sundry purposes; consequently, general ideology seems to be wide-ranging, which is characterised with broad terms. Moreover, the specific ideology could be slim to topical conceptual phenomenon (language, fashion, advertising, business, religion, education, discourse, music, feminism, etc.), whereas general ideology is an expansive system in a larger society (capitalism, socialism, etc.). Nevertheless, specific and general ideologies are neither opposing nor contradictory to each other as Blommaert $(2005,160)$ clarifies. Probably, the demarcations that scholars have provided in the concept of ideology are a matter of academic exercises for there is no serious thin line between the general and specific ideologies. Yuletide ideologies pitch their tent with specific ideology because it is narrowed down to topical image of Santa Claus. Advertisers tap the Yuletide ideology as a tool of power to persuasively inspire consumers' subconscious and conscious mental organisms as parts of the factors that determine decisions.

Let me give a warm up to this study by assessing complementary views of scholars on the matter of ideology. Friedrich explains that ideology is

a set of or at least amalgam of ideas, rationalisations, interpretations that mask or gloss over a struggle to get or hold onto power, particularly economic power, with the result that the actors and ideologues are themselves largely unaware of what is going on' (Friedrich 1989, 300)

Perhaps, ideology is a mixture of ideas that could be critically analytically explained. Friedrich configures ideology as a concealed concept in an attempt to secure power. This explains the essence that ideologues yearn for power. According to Friedrich, the reason could be to gain future economic benefits. With this primary purpose, there will be a course to propagate newly differentiated idea from such actors. The distinction in ideas will separate the ideas in the system of belief of social actor A from that of B. 
Competition might ensue when ideas are plotted on the statistical table of comparison, which can lead to the making of a choice. Ideologies provide observers as well as the society choices that lead to eclecticism. Owing to that claim, Fairclough (2003) opines that 'ideology is a representation of an aspect of the world which can be shown to contribute to establishing, maintaining and changing social relationship of power, denomination and exploitation' (Fairclough 2003, 9). Fairclough submits to the social relationship that is inculcated in ideology. In his view, establishment, sustenance and changing of existing ideas are the functions of ideology, most likely for exploitative purposes. It seems that ideology is the gathering of ideas as a weapon of manipulating the society for the propagators' advantages. As such, one might suggest that the most beneficiaries of ideological system are its promoters, carriers and actors.

Furthermore, van Dijk explicates ideology as a system of principles that organises social cognitions. Ideology mentally represents the basic social characteristics of a group. The concept also specifies basic framework of social cognition of internal structures (van Dijk 1995, 19, 21). Van Dijk's argument demonstrates a sort of interface operating in the society between the minds of the public and the actions taken. Ideology institutes ascendancy on the society by dominating the minds of the members of the society with prepositions in terms of identity, norms, goals, tasks, values, resources, positions, etc. which influence and compel the public to think, speak and act in the manner that the ideological campaigners decide. Ideologists are likely to be social dictators whose ideas are sold to the members of the society in a subtle manner and not anarchistic.

Interpellation is an ideological import, which is one of the elements of ideology that Althusser propounds. In Althusser's words, ideology interpellates subjects (Althusser 1971). As a way of providing a theoretical balance to this discourse, the concept of interpellation comes to the fore. Williamson (1995) explicates that 'this appellation itself involves an exchange: between you as an individual, and the imaginary subject addressed by the advert' (Williamson 1995, 50). Two subjects are advocated in the concept of interpellation. That is, a human being and a product. These entities seem to have different characteristics, yet, they are announced to have similar behavioural markers for achieving a particular goal. Particularly, Blommaert emphasizes that 'interpellation appeals to individuals to act in ... ways that reflect dominant ideologies' (Blommaert 2005, 162). Blommaert describes interpellation as a persuasive clause that stimulates the subject man with a certain product. In this regard, a product is characterised to reflect the individuals to possess similar representations. Symbolic elements are built in a product (as shown and discussed later in the study) so that the individuals could be identified with it as a reflection. The subject image featured in an advert is a manifestation of the characteristics of the larger society that the advert managers want the public to appreciate and embrace. It is further stated that 'ideology works through constituting (interpellating) persons as social subjects, fixing them in subject position while at the same time giving them illusion of being free agents' (Fairclough 1992, 30). The strategy is to remind people of whom they are; and whom they are not, yet, portraying them as whom they are not to be interchanged for whom they are.

The recruitment of interpellation, most especially in advertising, is a strange culture of putting consumers in the captivity of consumerism. The aim is to force the audience to buy what they need and perhaps what they do not need for the benefits of manufacturers. Despite that every human is elevated as possessing freedom and has the liberty to do what he/she likes within the arms of the law and to act liberally without acting under coercion; 
advertisers smartly, freely and willingly interfere and intrude into human liberty. Advertisers colour individuals with the norms in their products. The final destination for ideology, Zengele and Pitsoe (2004) claim, is the subject and hails individuals as subjects.

\section{Methodology}

The sources of the Santa Claus adverts presented for analysis were approached from several dimensions, among which are, the Internet, newspapers, signboards, and advertising shown in Lagos Countdown series. There is a need for this multifaceted approach to data collections because Santa Claus is a global figure that has been functioning for ages, and continues to make waves and to command respect from advertisers during the Yuletide season. The Internet was the major source of data on Santa Claus for some of the earlier and older adverts in this regard can barely be located from local archives in Nigeria. The CocaCola adverts in collaboration with Santa Claus styles - most especially those that were done in the past decades - were obtained from the Internet websites.

Besides, attempts were also made to get some of the texts from The Punch newspaper, signposts along the road and the adverts placed at the Lagos Countdown 2013 and 2015 (i.e. Yuletide programs organised by Lagos State Government). Specifically, the author monitored The Punch newspaper publications in December 2013 and December 2015 respectively to realise the necessary adverts associated with Santa Claus. In a quest to further obtain authentic primary data, the author was in a commercial bus one day, and sighted a young man reading a sports newspaper, named 'Complete Sports.' In the back page of the Complete Sport is an advert illustrated with Santa Claus. The permission of the owner was quickly obtained in order to take a picture of the advert. He granted the request and submitted the paper to us. With a Samsung WB50F camera, the concerned snappishly took the picture as one of the adverts on Santa Claus.

There is little doubt that Santa Claus has a few pictures to his credit because of the role he plays in the global scene, which advertisers have considered as a channel of communicating with consumers about their goods and services. Then, what the writer did was to select some earlier Santa Claus pictures to represent the above remark. As such, one picture of Santa Claus paraded before the influence of Coca-Cola was displayed as in Image 1; and five pictures of Santa Claus accommodated with the influence of Coca-Cola was selected as shown in Images 2, 3, 4, 5, and 6 in the literature review. This affiliation is necessary as a means of appreciating the efforts that the Coca-Cola Company has made all-this-while to promote the seasonal celebrated Santa Claus with the red-cum-white costume. For the purposes of analysis and discussions, all the other texts were presented alongside with Coca-Cola adverts. Four Coca-Cola adverts were chosen for analysis for a purpose of comparison, while one each was selected from the others. Coca-Cola seems to be interested in and associated with Santa Claus more than any other product. The experience gathered during data collection activities informs that claim. The concept of interpellation as central to advertising ideology is a theoretical device where the analysis and discussions were anchored. The study assesses only twelve ads for analysis. The symbol ' $($ ' connotes a registered company/product. 


\subsection{Data presentation}

Texts (Txs: 1-12) represent the data analysed in the study. The study locates them in the analysis and discussion section for good reading contacts.

\section{ANALYSIS AND DISCUSSION}

Txs:1-4 below are Coca-Cola ${ }^{\circledR}$ adverts. Out of the four Txs, only one does not show any verbal construction, that is $T x: 1$. Yet, there are significant messages embedded in the represented image.

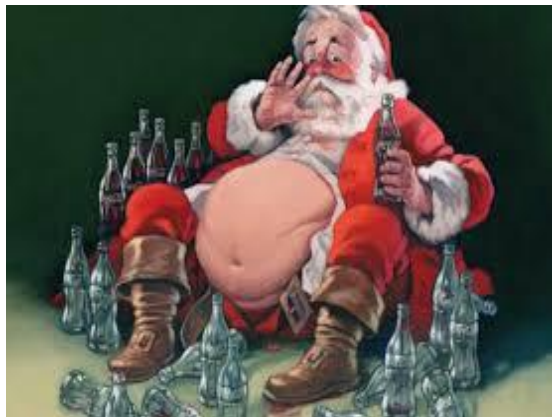

Text 1 Coca-cola Ad1

The Santa Claus is sitting down probably comfortably with about two dozens of empty bottles of Coke, whereas he is still in the process of consuming more contents. It seems that Santa Claus has the capacity to consume as many bottles of Coke as he likes, and as possible. This is demonstrated in the bottles (falling and standing ones) which lead to his grown pot-belly. By implication, the subject represents a social individual in the world who can also drink Coke the Santa Claus' way without giving cognizance to its sugar content.

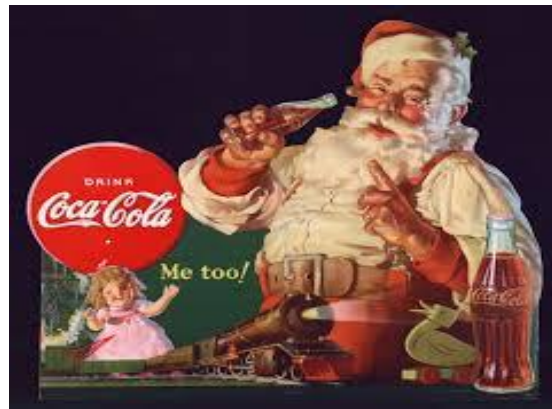

Text 2 Coca-cola Ad2

Four significant semiotics are represented in $T x: 2$. These are: Santa Claus, baby girl, Coke bottles and texts. Santa Claus illustrates with his two fingers that he has two bottles of Coke, one is opened and in his hand raised close to his mouth, and the other placed on his table is yet to be open. The text's command is 'Drink Coca-cola.' The little kid is enthusiastic to drink as commanded. Her request is 'Me too!' However, the decision of 
Santa Claus has not been made known despite his generosity. His action indicates that Coke is a fantastic soft drink that children should be eager to consume. Those who are eager to enjoy Coke must be as fast as possible to get one because the competition the lovers of Coke might be involved in getting it could be great. Coke, to the advertiser, is fast selling and children are always excited to get one bottle. Drinking Coke provides a fantastic experience that every child is keen to have. This is supported with the phrase, 'Me too!' 'Me too!' is an elliptical declarative where the subject and predicator are taken away leaving alone the object, and adjunct that reverberates.

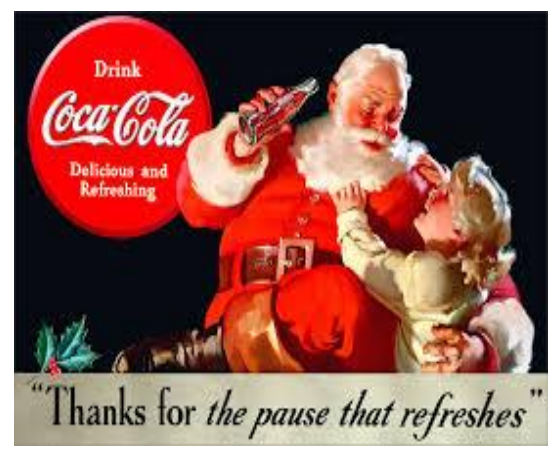

Text 3 Coca-cola Ad3

Aside the images of Santa Claus and a little babe, where the little babe struggles to share the bottle of Coke available with Santa Claus, there are two clauses that depict the messages that the advertisers are intended. These clauses are 'Drink Coca-cola delicious and refreshing' and 'Thanks for the pause that refreshes.' The first clause is imperative while the second is a minor clause. The fight for a bottle of Coke between Santa Claus and the girl could have a psychological effect on children who, one could say, possess the characteristics of love for one another, and emulating one another (Dalamu 2017a). Santa Claus is known to be a gift-giver to children; for him to be directly attempting to struggle and probably denying the babe of a bottle of Coke available in his hand, the summation could be that Coke is precious. Santa Claus could afford to give all manner of gifts to children but not a bottle of Coke. Santa Claus, by his action, is responding that 'little girl, go and get your own bottle.' This might be the motif for the following linguistic expressions that serve as Santa Claus' own words: one, drink Coke because of two distinctions - deliciousness and refreshment traits; two, people need to show appreciation to Coke for a reason that the pause it gives us refreshes all the time. 'The pause that refreshes' stimulates the writer to flash-back in the Coke's 1931 slogan created by an illustrator Haddon Sundblom as illustrated in Image 2.

The action of Santa Claus to the little girl could be equated to the biblical ten virgins where only five were wise and the other five were foolish (Matthew 25, 1-9). The foolish five requested oil from the five wise ones in the midnight. However, the reply of the wise five to the foolish five is that 'No, lest there should not be enough for us and you: but go rather to those who sell and buy for yourselves.' Santa Claus is constructed to be greedy and selfish perhaps for the first time in the matter of drinking Coca-cola, yet, generous in all the other things. The message of Coke to those who want to enjoy its deliciousness and refreshment in every pause is to go and buy theirs. It really signals that if a generous 
Santa Claus can be greedy in the matter of Coke, then there is something special about the product. The advertiser tries as much as possible to avert the going-on, 'buy', yet the consumers are expected to realise that euphemism themselves from the harmony that the advertising frame displays.

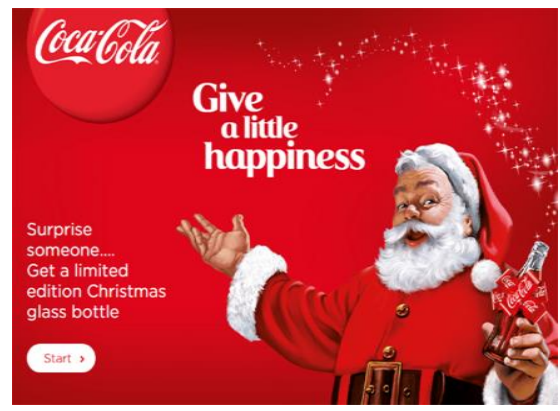

Text 4 Coca-cola Ad 4

$T x: 4$ operates in the same communicative form with the other Coke adverts (shown in Txs: 1-4 in the Appendix) in terms of the images of Santa Claus and Coke but differs in the frequency of textual constructs. Apart from the logo of Coca-cola that is in the text, there are three imperatives in the frame thus: (i) 'Give a little happiness'; (ii) 'Surprise someone...'; and (iii) 'Get a limited edition Christmas glass bottle.' 'Give', 'Surprise', and 'Get' are markers of commands that have the intrinsic 'you' as their sole subject. The 'you' refers to an individual or collective individuals expected to act as the narrator, Santa Claus, as he enjoins readers through the frame. Santa Claus commands consumers to give Coke to someone as a surprise which will in-turn make the person happy. The buying should be activated as quickly as possible because the Christmas Coke seems unusual. Persuasion is a primary function of advertisers (Goldman 1992). The fundamental is depicted in Christmas Coke as a superb product than the usual Coke. In a real sense of the persuasive game, the content of the glass bottle of Coke may not have changed; the advert only has changed. This is a winning strategy aiming at influencing consumers. The tactic is as well as indirectly denying the recipients of freedom of choice fabricated through paradigmatic apparatuses of linguistic framework in the advertising plate.

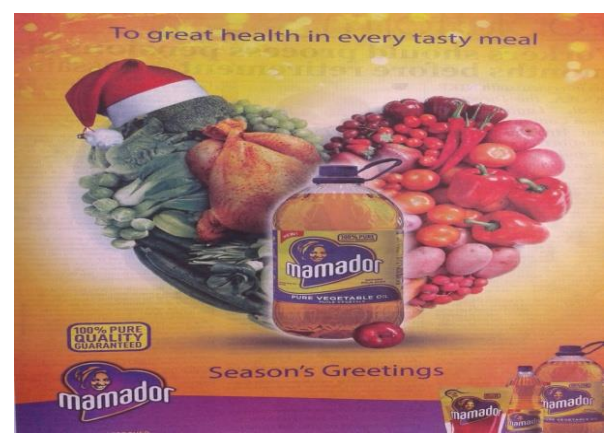

Text 5 Mamador Ad 
$T x: 5$ advert is about Mamador ${ }^{\circledR}$ Pure Vegetable Oil. The images in the advert are many, among which are, tomatoes, pepper, chicken and the Mamador emblem of a woman enclosed in a symbol of love. There are different sizes and shapes of Mamador oil packages. One also observes that the cap of Santa Claus is placed on some of the soup ingredients in which a container of Mamador is symbolically placarded as a phenomenal object. The placement position of a Mamador bottle indicates its principal role in cooking activities. Without Mamador, all the other ingredients remain raw and cannot be good for human consumption. Mamador prepares them for consumption in all seasons and most especially during the Christmas. As numerous as the ingredients are, and as basic as Mamador is, Santa Claus could not be left out of the cooking. So, Mamador, as revealed in $T x: 5$, seeks his approval in order to convince consumers of its qualities. Mamador identifies with Santa Claus not only as its crown but also as a promoter of all the ingredients that could make up a soup. Some of Mamador qualities are shown as 'provision of great health', ' $100 \%$ pure', and 'meant for the good.' 'The good' in Mamador's context is hazy and ambiguous. Does 'the good' mean those who are good in character as a virtue? Or those who behave well in the kitchen? Or those who are encouraged to buy Mamador? A lot of other questions beg for answers from the advert. Besides, irrespective of the semiotic ingredients on the Mamador advertising frame, it is vital for consumers to realise that Santa Claus has approved of Mamador oil for the cooking during the Yuletide season. That is the characteristic ideological interchangeability that the advertiser intends to achieve. Such partnership works in business as a means of augmenting the sales growth. When it comes to the cooking time, as the advertiser advises, consumers should do the cooking with Mamador to enjoy the food.

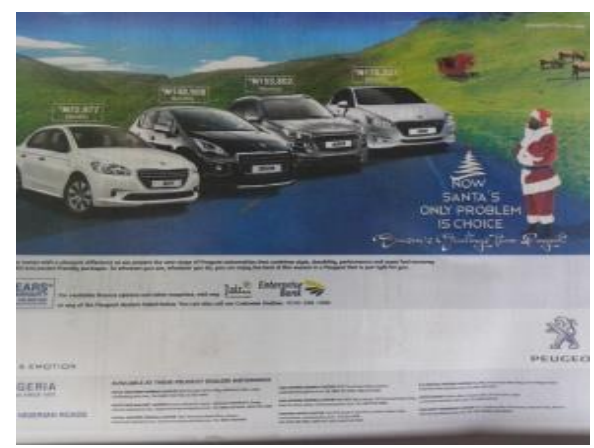

Text 6: Peugeot Ad

The relationship between Santa Claus and Christmas are shown in Tx: 6 . The framework accommodates the carrier's cart, animals feeding on grasses, and Santa Claus. There are also four brand new Peugeot ${ }^{\circledR}$ cars in front of Santa Claus. The advert shows that Santa Claus has abandoned both the carrier's cart and the animals with his interest remaining on the cars. The historical consequence is that the pious Santa Claus lived around 280 A.D. when cars were not available, and without nominal linguistic determinisms (Yule 1985). It is quite unfortunate that the civilised Santa Claus has abandoned his traditional carrier's cart of old to eyeing the stylish and attractive cars of the $21^{\text {st }}$ century. The Santa Claus of the olden days may be renowned along with its carrier's cart. The Santa of this dispensation, as Peugeot portrays him, is as civilised as other men of this generation. Thus, he is a wise Santa tired of his 'push-me-I-go' vehicular device without automotive engine. This is the 
reason for him to appreciate modern cars and desires to have them. Peugeot indicts Santa Claus that 'Now, Santa's only problem is choice' having abandoned his fundamental functions to a burning desire of buying a car.

'Now', an adjunct of time, signals the current situation of Santa Claus as the icon is confronted with optional Peugeot cars thinking about which of the varieties that one should give a preference to purchasing. In the $4^{\text {th }}$ century, choice was not a challenge to Santa because he could not desire cars he did not see. Now that Peugeot car brands are available, Santa is dreaming of making a choice. That is, a choice of selecting a beautiful car out of many others. The advertiser interpellates Santa for the subject individual to desire a brand of Peugeot car and make a choice. The exchange is obvious when the price (monthly instalment) is made available for 'you', the subject. It is nice to remember that the public persona, Santa Claus, shows up once in a year during the Yuletide season. Would Peugeot want to sell to Santa Claus every year? How many Peugeot cars can Santa Claus buy and ride? How much will Santa Claus go to the extent of buying Peugeot cars that can give the company enough sales? These are questions generated to affirm the notion of interchangeability in the Peugeot's advert ideological expression. Santa Claus serves as an iconic object that can skyrocket the sales of Peugeot cars.

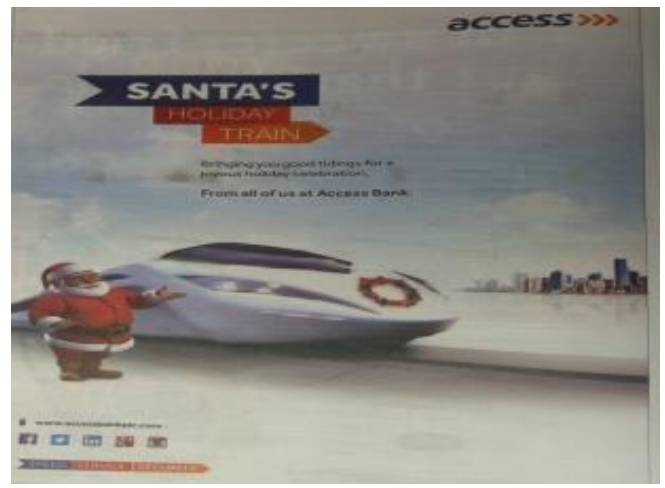

Text 7 Access Bank Ad

Another modernised Santa Claus is propagated in the Access Bank ${ }^{\circledR}$ advert. The Santa Claus is articulated in the standardised Coca-cola red and white apparel, however, his traditional carrier's cart is replaced with a modern day train, tagged, 'Santa's Holiday Train.' The train, instead of the cart, is used to bring good tidings for joyous holiday celebration. What exactly can one say that the bank is advertising here? Nothing, of course! Two things emerged significantly in the advertising communication. One, there is an expression of greeting to everyone during the season with an inscription 'From all of us at Access Bank.' Two, the advert serves as a sort of identification with the people as their individuals are exchanged for Santa Claus. Similar pictorial accounts of Santa Claus are located in Milo ${ }^{\circledR}$, Maggi ${ }^{\circledR}$ and Power Horse ${ }^{\circledR}$, that is, Txs: 8, 9 and 10. An elliptical sign of Santa Claus is obtained to project meaning potential the adverts. The cap of Santa Claus signifies the presence of Santa Claus in the products. These representations seem the same as if there are collaborating efforts from the three advertisers to present Milo, Maggi and Power Horse in the same manner. Unfortunately, except that Milo and Maggi are products of the same manufacturing company, the author's investigation shows that the trio patronizes different 
advertising firms and agents. The full representation of Santa Claus may not be of interest to advertisers, what is crucial to them is the iconic illustration of the personality of Santa Claus. That is why his cap, as a symbol, dictates the pace of the adverts.

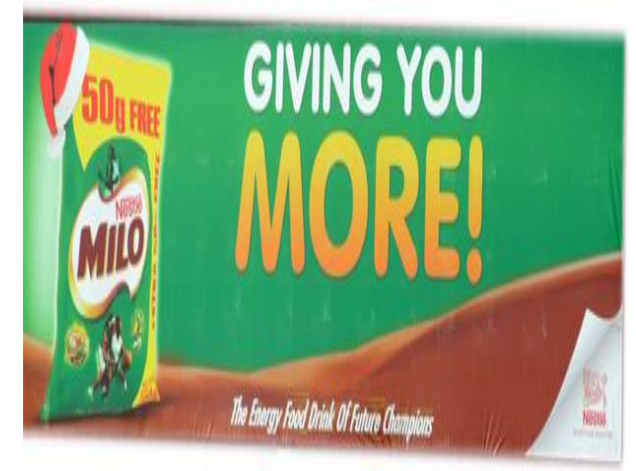

Text 8 Milo Ad

It is inscribed in Tx:8 thus; 'giving you more.' 'Giving you more' can be translated as a means of complementing the nature that characterises Santa Claus as a free gift-giver. Ideally, Milo does not intend to give anyone a free drink. Nevertheless, as an entity that presents itself parallel to Santa Claus attributes, 'giving' is adopted as a winning tool. The key of 'giving' in Milo is simply that the bar of its content size represented in grams has been raised from ' $40 \mathrm{~g}$ ' to ' $50 \mathrm{~g}$.' The free gift is the extra $10 \mathrm{~g}$ added to the former. Does that indicate whether the price will be increased, or remain the same, or decrease a bit? Nevertheless, the actual price is not indicated in the advertising frame, whereas Milo is projected as giving consumers more value for their money. This is a mere persuasive expression because whatever any advert portrays, as manufacturers' hidden spokesperson or dramatis persona, is simply done to assist manufacturers to sell more products to consumers. That choice can increase sales and make more profit probably at the expense of consumers.

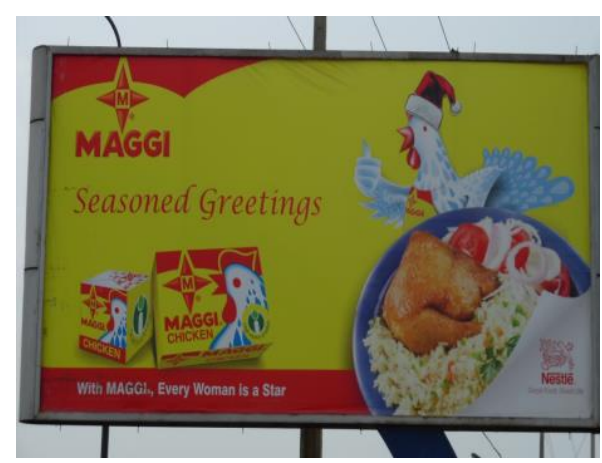

Text 9 Maggi Ad 
Anyone the cap fits let the individual wear it has been a recurring metaphor from the inception among human beings. However, is it turbulent when an animal wears a cap? To advertisers, it is not chaotic but a schema to attract as well as sensitise consumers. A bird wears a cap; a cap that is socially prominent, and of course a Santa Claus cap for that matter! Maggi chicken, as the name implies, interpellates the chicken for a human being. The personified chicken sends 'seasoned greetings' to consumers. The chicken represents Santa Claus as an avenue to create awareness of his coming and importance during the Christmas. Worth-noting is the minor clause 'seasoned greetings' displays how 'season' is de-nominalised to an adjective 'seasoned.' One could have assessed 'seasoned' as ambiguous, but from the contextual application it is a conversion of 'seasoning' whose family specie, Maggi, belongs to 'seasoned.' The primary implication is that Maggi seasoning sends greetings to all consumers during the Yuletide.

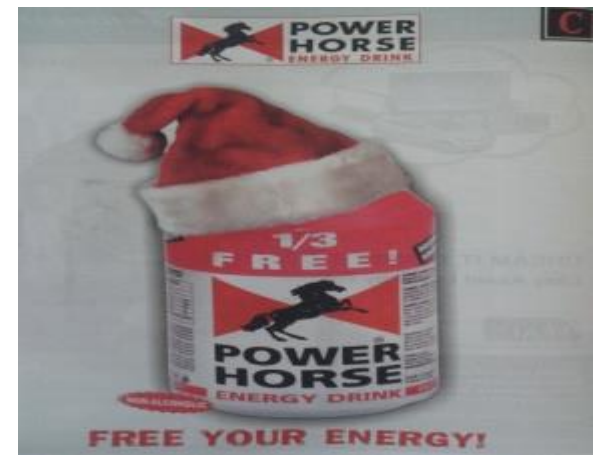

Text 10 Power Horse Ad

Equus Ferus Caballus is the alternative name (botanical/zoological name) for the horse. It is a solid-hoofed herbivorous quadruped domesticated animal since prehistorical times. The horse could be further labelled as a very strong animal that people use for pulling and carrying heavy loads. Despite these defining features, the signature of Santa Claus is important for selling a product named after the animal. The elliptical appearance of Santa Claus in the form of his cap does not only indicate a selling power but also makes the communication glamorous. From all indications, Santa Claus has never been revealed as an energiser. He is connected to righteousness, giving gifts, helping people and working miracles from the historical and religious points of view. Looking at the relationship Power Horse tries to build with him, one could argue that Santa Claus and Power Horse have nothing in common. History has failed to explicate Santa Claus as a power giver or power syndrome or alcoholic friendly. The advert comes to the fore this season as a mere identification which attempts to seek people's attention for the purpose of sales. Thus, the advertising professional enjoins people to be free or to release some energetic strength which is not in any way one of the dominant principles of Santa Claus. The strategy is a strong indicator of how advertisers systematise contradictory objects to engineer persuasion. 


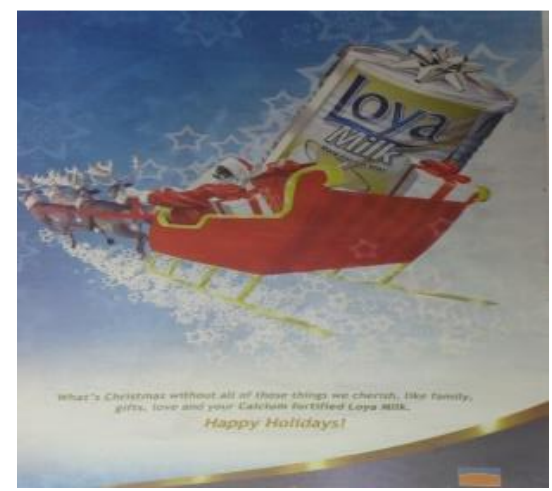

Text 11 Loyal Milk Ad

Loyal Milk ${ }^{\circledR}$ depicts Santa Claus' participation in the advert from a different angle. The dimension in Tx: 11 shows Santa Claus as a flying being whose motional activity is championed by four deer. Can deer fly like birds? The answer is not in affirmative! The Loyal Milk's deer do not only fly, they assist in flying Santa Claus in a chair-like object with an unusual size of a tin of Loyal Milk and a gift is attached to the can. In a very simple term, the four deer are burden-bearers. An emphasis on fun is laid in the advert by seeing Santa Claus sitting down comfortably in the chair-like object looking back still. His looking back might be interpreted as responding to the feelings of the onlookers as the Loyal Milk is flying along with this celebrated icon. Where is Santa Claus taking the milk to? Who is Santa Claus going to give the milk to? These are likely queries in the minds of Santa Claus' friends. Though the referring friends of his are not reflected in the ad, notwithstanding, Santa Claus creates a show business in which spectators are meant to be part of the scene.

It is substantial to mention that Santa Claus has been seen as a public persona who lives in Rome. The to and fro movement is not unconnected to Rome. Neither coming from Rome to Nigeria nor going back to Rome from Nigeria is a journey that could be done speedily easily without an aircraft. The chair-like object is the impressionist symbol of Santa Claus' plane that conveys him every year he comes to Nigeria from Rome and returns to Rome. Things that customers cherish are identified in the ad, apart from the product, and those things are culminated with Loyal Milk and greetings. It reads in part 'What's Christmas without all those things we cherish, like family, gifts, love and your calcium fortified Loyal Milk. Happy Holidays!' One of the most meaningful subjects in the text is 'your.' 'Your' is employed to associate consumers with Loyal Milk during Christmas. The claim, in the communicator's point of view, is that Loyal Milk should be a priority among other things that consumers should value in the season. 


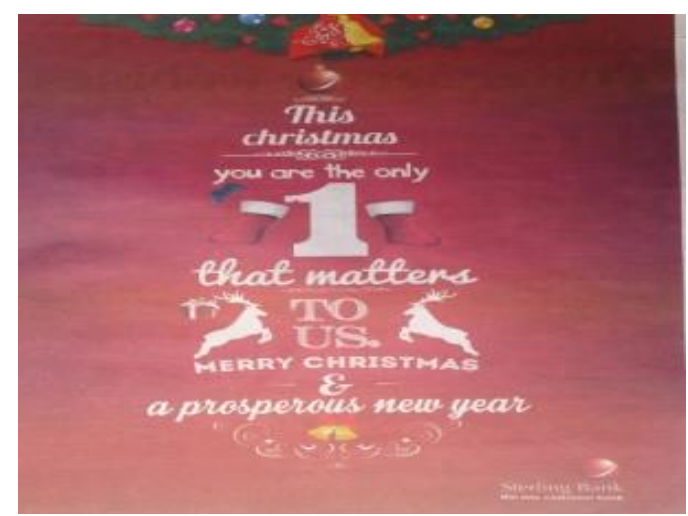

Text 12 Sterling Bank Ad

In $T x: 12$, Sterling Bank ${ }^{\circledR}$ demonstrates its identification with Santa Claus through his legs. The popularity of Santa Claus is something else, something to ride home about, and something to reckon with. He has turned to a household figure not only in the West but also in Nigeria. His renowned figure has gone virile to an extent where the saint does not need to portray his complete posture before a proper identification is observed. Every part of Santa Claus is an asset with significance. As long as a part of his Coca-cola standardised red-white dress colour is shown, there is no constraint to his recognition. Whether his legs, cap, or staff is shown, people will surely acknowledge the object as Santa Claus for his distinct colourful appearance. The two legs of Santa Claus are shown with the numeral ' 1 ' separating them. There are linguistic structures accompanying the pictures. That is, 'This Christmas you are the only 1 that matters to us' and 'Merry Christmas and a prosperous new year.' The linguistic devices are referential. The constructs are further supported with structural 'sets'. Besides the Santa Claus picture, there are two pictures of deer separated with 'TO US'. A close look at the text reveals the emphasis on 'you'. 'You' represents the spirit of community (Jetten, Postmes \& Mcauliffe, 2002) in the customers of Sterling Bank who identify with Santa Claus and at the same time represented by Santa Claus.

\section{CONCLUSION}

The common module in all the adverts is the image of Santa Claus in different shapes and sizes. Some of the images are ellipted with some portions not featured. A minimum of two ideologies are created in the adverts; one, the world of Santa Claus, and two, the world of the products. The culture of Santa Claus serves as a means of transference where the meaningful use of the products is decoded through the image of Santa Claus. In the construct of the meaningful relationships, Santa Claus generates currency for the interpellated products. The products campaigned to consumers are presented in the status of Santa Claus. Sometimes, advertisers seem to be contradictory in a way. Santa Claus is a giver and not a receiver. However, the depicted subject in the adverts receives nothing free from the companies-cum-products. Whatever consumers buy with their money is what they get from the company and the value that they derive from the products. It is the companies that receive cash from the consumers and not vice versa. As such, the ideological projection 
is contradictory. Human consumers, that is, the individuals replicated in the adverts are Santa Claus entities who give something for the survival of the companies identified themselves with Santa Claus. It is not the companies or products that are Santa Claus but the subject 'you' which is most times intrinsic. Companies, and advertised goods and services in the frames are beneficiaries of Santa Claus and the consumers seem to be benefactors. Each advertiser only personalises the product in relevant to Santa Claus' attributes for personal gains. Their actions can be recapitulated and connected to a proverbial discoursal hypocrisy of 'do as I say.'

Beyond the business platform, Santa Claus is a symbol of unification. It has the capability to merge the world as a peaceful and indivisible entity that propagates love. The author appreciates advertisers who remind the public of the past though with a principal aim of influencing people's thoughts in order to sell their products. Therefore, it is my opinion that governments and institutions should support the further propagation of the persona as an object of negotiating peace in our world and not just a fun of it. If it is possible that something similar to Santa Claus could be created beyond religious affiliations as a campaign for peace that should be done as quickly as possible. This can be a quarterly event organised and supervised by the United Nations and the G7. Tracing the historical herald and development of Santa Claus from Saint Nicholas to the present day should not only be an academic exercise but rather a practical endeavour of peace emancipation in the entire universe.

\section{REFERENCES}

Althusser, L., (1971), Ideology and Ideological State Apparatuses: Lenin and Philosophy and Other Essays, translated by Ben Brewster, London, New Left Books.

Blommaert, J. (2005), Discourse, Cambridge, Cambridge University Press.

Clampin, D., (2014), Advertising and Propaganda in World War II, London, I.B. Tauris \& Co. Ltd or Philip Wilson Publishers Ltd.

Dalamu, T., (2017a), Nigerian Children Specimens as Resonance of Print Media Advertising: What for? Communicatio, 11(2), 79-111.

Dalamu, T., (2017b), Maternal Ideology in an $\mathrm{MTN}^{\circledR}$ Advertisement: Analysing Socio-Semiotic Reality as a Campaign for Peace. Journal of Language and Education, 3(4), 16-26. doi:10.17323/2411-7390-2017-3-4-16-26.

Fairclough, N., (2003), Analysing Discourse: Textual Analysis for Social Research, New York, Routledge.

Fairclough, N., (1992), Discourse and Social Change, Malden, USA, Polity Press.

Fairclough, N., (2001), Language and Power, Edinburg, Pearson Educational Limited.

Feyerabend, P. K., (1970), Against Method, London, Verso.

Friedrich, P., (1989), "Language, Ideology and Political Economy,” American Anthropologist 91, pp. $295-312$.

Green, C. R., (2015), "St Nicholas of Myra: A Guide to the Real Santa Claus", The History of Santa Claus and Father Christmas, 2015, http://www.arthuriana.co.uk/xmas/pages/origins.htm

Goldman, R., (1992), Reading Ads Socially, London and New York, Routledge.

Green, C. R., (2004, 2012), "St Nicholas of Myra: A guide to the Real Santa Claus", The History of Santa Claus and Father Christmas, http://www.arthuriana.co.uk/xmas/pages/santa.htmState

Harper's Weekly, (1897), September 12, 2014, https://prezi.com/z/2h2hpsvkofvc/harpers-eekly.

Holy Bible, (1982), "Matthew", New King James Version, Nashville, Thomas Nelson Inc.

Jetten, J.; Postmes, T.; \& Mcauliffe,B. J.; (2002), "We're all Individuals: Group Norms of Individualism and Collectivism, Levels of Identification and Identity Threat", European Journal of Social Psychology 32, 189-207. DOI: 10.1002/ejsp.65, http://www.iaccp.org/sites/default/files/jetten_postmes_mcauliffe_2002_0.pdf

Johnson, B. (1616), Christmas, His Masque: A Play, http://www.johnsanidopoulos.com/2009/12/fatherchristmas-and-christmas-spirit.html

Johnson, B., (1686), The Examination and Tryal of Father Christmas, http://www.johnsanidopoulos.com/ 2009/12/father-christmas-and-christmas-spirit.html 
Matthew, H., (2015), History of the Coca-Cola Christmas Trucks, http://www.coca-cola.co.uk/stories/the-taleof-the-christmas-trucks

Mikkelson, D., (2014), The Claus that Refreshes. Was the Modern Image of Santa Claus Created by the CocaCola Company?, http://www.snopes.com/holidays/christmas/santa/cocacola.asp

No Author, (nd), "The Modern Image of Santa Claus Has Been Refined Again and Again", Evolution of Santa Claus, http://www.history.com/topics/christmas/santa-claus

No Author, (2003), "The Museum of Unnatural Mystery", AKA Santa Claus, http://www.unmuseum. org/santa.htm

Pollay,R. W., (1978), “Wanted: A History of Advertising,” Journal of Advertising Research 18, vol. 5: pp. 63-68.

Simpson, J., \& Roud, S., (2001), The Oxford Dictionary of English Folklore, Oxford, Oxford University Press.

Staff, J., (2014), Coca-Cola and Father Christmas: The Sundblom Santa Story, http://www.cocacola.co.uk/stories/coca-cola-and-father-christmas-the-sundblom-santa-story

Staff, J., (2016), Coca-Cola's Christmas ad: Holidays Are Coming!, http://www.coca-cola.co.uk/stories/ holidays-are-coming

Swartz, B. K., (n.d.). The Origin of American Christmas Myth and Customs, http://www.arthuriana.co.uk/ xmas/swartz/American\%20Christmas\%20Origins.htm

Twitchell, J. B., (2000), Twenty Ads that Shook the World: The Century's Most Groundbreaking Advertising and How it Changed Us All, New York, Random House Inc. http://www.history.com/topics/ christmas/santa-claus

van Dijk, T., (1995), "Discourse Analysis as Ideology Analysis," Language and Peace, 17- 33

Williamson, J., (1995), Decoding Advertising: Ideology and Meaning in Advertising, New York, Marion Boyars.

Woodbridge, L., (1987), "Black and White and Red All Over: The Sonnet Mistress Amongst the Ndembu," Renaissance Quarterly 40, vol. 2,: pp.247-97, 274-5.

Zengele, T., \& Victor Pitsoe, V., (2004), "Louis Althusser on Politics and Processes of Filling Promotional Posts," Mediterranean Journal of Social Sciences (MCSER Publishing) 5, Vol. 2: pp. 333-340.

Yule, G., (1985), The $e$ Study of Language, Cambridge, Cambridge University Press.

\section{BOŽIĆNA IDEOLOGIJA KAO REKLAMNA IDEOLOGIJA: ISTORIJSKI OSVRT OD SVETOG NIKOLE DO DANAŠNJEG DANA}

Ovo istraživanje bavi se istorijskim fenomenom Svetog Nikole, ličnosti koja je najpoznatija kao Deda Mraz. Cilj je da se pokaže da reklamne agencije koriste vrline Deda Mraza kako bi ubedile potrošače da kupuju. Zbog interdisciplinarnosti ovog istraživanja, koje seže delom u istoriju, delom u lingvistiku i marketing, koncept ideologije koristi se, između ostalog, kao analitičko sredstvo kako bi se otkrio potencijal za konstruisanje značenja. Autor analizira dvanaest reklama, od kojih šest Koka-kolinih, u kojima se koristi lik Deda Mraza kao simbol časti, $i$ u kojima se promoviše herojska ličnost. Analizom se došlo do zaključka da je Deda Mraz univerzalna i opšte-prihvaćena figura na globalnom nivou tokom božićnih praznika. Ta hegemonija njegovog uticaja zaslužna je za činjenicu što ga stručnjaci marketinga predstavljaju kao učtivog čoveka, pa je on često prikazan kao kuvar, golub ili anđeo, ljubitelj ili vlasnik automobila, alkoholičar ili ljubitelj alkohola, ili pak kao bankar. Deda Mraz sa svojim tradicionalnim vrednostima koje se ispoljavaju u vidu dobročinstva prema celom ljudskom rodu, prikazuju se još $i$ kao štedljiva osoba sa velikom ljubavlju prema slatkišima bez neželjenih posledica po zdavlje. Sve u svemu, tradicionalna pravila ponašanja Deda Mraza, koja potiču od Svetog Nikole, a koja promoviše Koka-kola, predstavljaju nešto čega, prema rezultatima istraživanja, svi treba da se pridržavamo. Možda bi kroz ovaj vid usvajanja karakteristika političko nasilje i terorizam pred kojima drhti ceo svet mogli da se spreče za znatno manje vremena i sa mnogo manje troškova.

Ključne reči: marketing, Koka-kola, ideologija, interpelacija, Deda Mraz 